\title{
ANALISIS PENGARUH PEMBENGKOKAN PADA ALAT UKUR TINGKAT KEKERUHAN AIR MENGGUNAKAN SISTEM SENSOR SERAT OPTIK
}

\author{
Mardian Peslinof ${ }^{1}$, Harmadi $^{2}$ dan Wildian ${ }^{2}$ \\ ${ }^{1}$ Program Pascasarjana FMIPA Universitas Andalas \\ ${ }^{2}$ Departemen Fisika, FMIPA Universitas Andalas, Padang 25163 \\ Email : ${ }^{1}$ peslinov_physic05@yahoo.com; ${ }^{2}$ harmadi@fmipa.unand.ac.id
}

\begin{abstract}
ABSTRAK
Telah dirancang sistem sensor serat optik untuk mengukur tingkat kekeruhan air dengan model $U$-system. Rancangan sistem terdiri dari pemancar berupa LED merah $(660 \mathrm{~nm})$, serat optik FD 620 10, fotodetektor OPT101, mikrokontroler ATMEGA32 untuk memproses masukan detektor, dan LCD untuk penampil. Serat optik sepanjang $30 \mathrm{~cm}$ dikupas claddingnya pada bagian tengahnya sepanjang $5 \mathrm{~cm}$. Pengumpulan data dilakukan dengan membandingkan hasil keluaran dari detektor dari beberapa variasi sudut pembengkokan serat optik terhadap larutan yang telah diketahui nilai kekeruhannya. Pemberian variasi sudut pembengkokan memberikan perbedaan sensitivitas pada pengukuran. Dengan menganalisa nilai keluaran sensor akibat pembengkokan, didapatkan besarnya rugi daya yang dialami sensor sebanding dengan besarnya sudut pembengkokan yang diberikan. Semakin besar sudut yang diberikan maka akan semakin tinggi sensitivitas pengukuran, namun terdapat suatu keadaan dimana apabila sudut diperbesar lagi maka sensitivitasnya berkurang.
\end{abstract}

Kata kunci : kekeruhan air, serat optik, sensitivitas, pembengkokan (bending)

\section{PENDAHULUAN}

Air bersih secara fisis diindikasikan dengan keadaannya yang bening, tidak berwarna dan tidak berbau. Kondisi seperti ini terjadi jika air tidak dikotori oleh bahan organik atau anorganik. Sedangkan secara optis, air yang tercampuri oleh bahan pengotor keadaannya akan mengalami perubahan, mungkin menjadi berwarna atau menjadi keruh. Kekeruhan air disebabkan oleh zat padat yang terlarut, baik yang bersifat anorganik maupun yang bersifat organik[1]. Tingkat kekeruhan dapat diketahui dengan menggunakan alat ukur turbidimeter. Perkembangan ilmu pengetahuan dan teknologi yang demikian pesat di bidang elektronika dan instrumentasi telah memungkinkan diciptakannya alat-alat ukur yang bekerja secara tepat dan praktis.

Serat optik dikembangkan menuju kearah sistem sensor yang dimodifikasi dan digunakan sebagai perangkat yang berinteraksi langsung dengan lingkungan. Penerapan serat optik sebagai sensor salah satunya dapat digunakan untuk pengukuran tingkat kekeruhan air. Serat optik memiliki banyak kelebihan seperti kecepatan, tahan terhadap pengkaratan, dan harga relatif terjangkau[2]. Sistem sensor serat optis dirancang dengan menggunakan serat optik multimode. Bagian sensor penginderanya dilakukan dengan memodifikasi kabel serat optik, dimana pada bagian tengahnya mengganti cladding asli dengan kekeruhan.

Pembengkokan serat optik menyebabkan cahaya yang merambat pada serat optik berbelok dari arah transmisi dan hilang, sehingga akan terjadi rugi-rugi pada serat optik. Rugi-rugi ini mengakibatkan berkurangnya intensitas cahaya yang menjalar. Misalnya pada serat optik yang mendapat tekanan cukup keras dapat menyebabkan ukuran diameter serat optik menjadi berbeda dari diameter semula, sehingga mempengaruhi sifat transmisi 
cahaya di dalamnya. Rugi-rugi akibat pembengkokan serat optik dibedakan menjadi dua macam yaitu pembengkokan makro dan pembengkokan mikro[3].

Rugi-rugi pembengkokan makro terjadi ketika sinar atau cahaya melalui serat optik yang dilengkungkan dengan jari-jari lebih lebar dibandingkan dengan diameter serat optik. Berdasarkan prinsip pemantulan dan pembiasan cahaya, jika sudut datang lebih kecil dari sudut kritis, maka moda cahaya tidak dipantulkan secara sempurna melainkan lebih banyak dibiaskan keluar dari inti serat optik. Sedangkan untuk sinar yang membentuk sudut datang lebih besar dari sudut kritis, sebagian besar moda cahaya akan dipantulkan kembali masuk ke dalam selubung seperti halnya prinsip pemantulan total. Kondisi ini mengakibatkan perubahan moda yang dihasilkan. Pembengkokan mikro terjadi karena ketidakrataan pada permukaan batas antara cladding dan core secara acak atau random pada serat optik. Hal ini disebabkan karena proses pembuatan kabel ataupun ketika proses penarikan saat menggunakan kabel tersebut[4].

Sistem pengukuran kekeruhan air ini menggunakan sistem sensor serat optik dengan metode evanescent. Gejala evanescent terjadi pada penjalaran cahaya di dalam serat optik, gelombang cahaya akan mengalami pantulan internal total berulang-ulang pada batas antara inti dan cladding. Berkas cahaya itu akan tumpang tindih antara berkas datang dengan berkas bias sehingga menimbulkan medan yang menembus kedalam cladding. [5]. medan evanescent diekspresikan dengan Persamaan 1.

$$
E_{z}=E_{0} \exp \left[-\frac{z}{d_{p}}\right]
$$

Dimana $\mathrm{z}$ merupakan jarak penjalaran gelombang cahaya, $E_{0}$ merupakan medan gelombang mula-mula, dan $d_{p}$ adalah penetration depth. Penetration depth merupakan kedalaman gelombang memasuki cladding.

\section{METODE PENELITIAN}

Penelitian terhadap alat ukur tingkat kekeruhan air menggunakan sistem sensor serat optik ini dilakukan di Laboratorium Elektronika dan Instrumentasi Jurusan Fisika FMIPA Universitas Andalas. Dalam melaksanakan penelitian ini peralatan yang digunakan terdiri dari multimeter digital, solder, dan turbidimeter. Dalam pembuatan alat ukur tingkat kekeruhan air menggunakan sistem sensor serat optik dibutuhkan kabel serat optik plastik FD 620 10, larutan sampel, dan komponen elektronika meliputi kapasitor, resistor, fotodioda OPT 101 dan LED merah.

Sistem sensor ini dibuat dengan memodifikasi cladding kabel serat optik. Modifikasi dilakukan dengan cara mengupas cladding aslinya. Rancangan sensor ini mengambil serat optik sepanjang $30 \mathrm{~cm}$. Modifikasi ini dilakukan dengan cara mengupas jaket serat optik terlebih dahulu dengan cutter sepanjang $5 \mathrm{~cm}$. Cladding dikupas dengan cara pemolesan pada permukaan serat optik. Pemolesan dilakukan dengan menggunakan kertas gosok yang paling halus, pemolesan ini dibantu dengan larutan aseton. Pemolesan dilakukan secara perlahan dan searah sampai terdapat indikasi cladding terlepas. Indikasi terlepasnya cladding dapat diketahui ketika sudah terdapat kebocoran daerah sensing apabila dilalui cahaya, dimana hal ini dapat terlihat dengan mata. Secara umum blok diagram sistem secara keseluruhan seperti Gambar 1. 


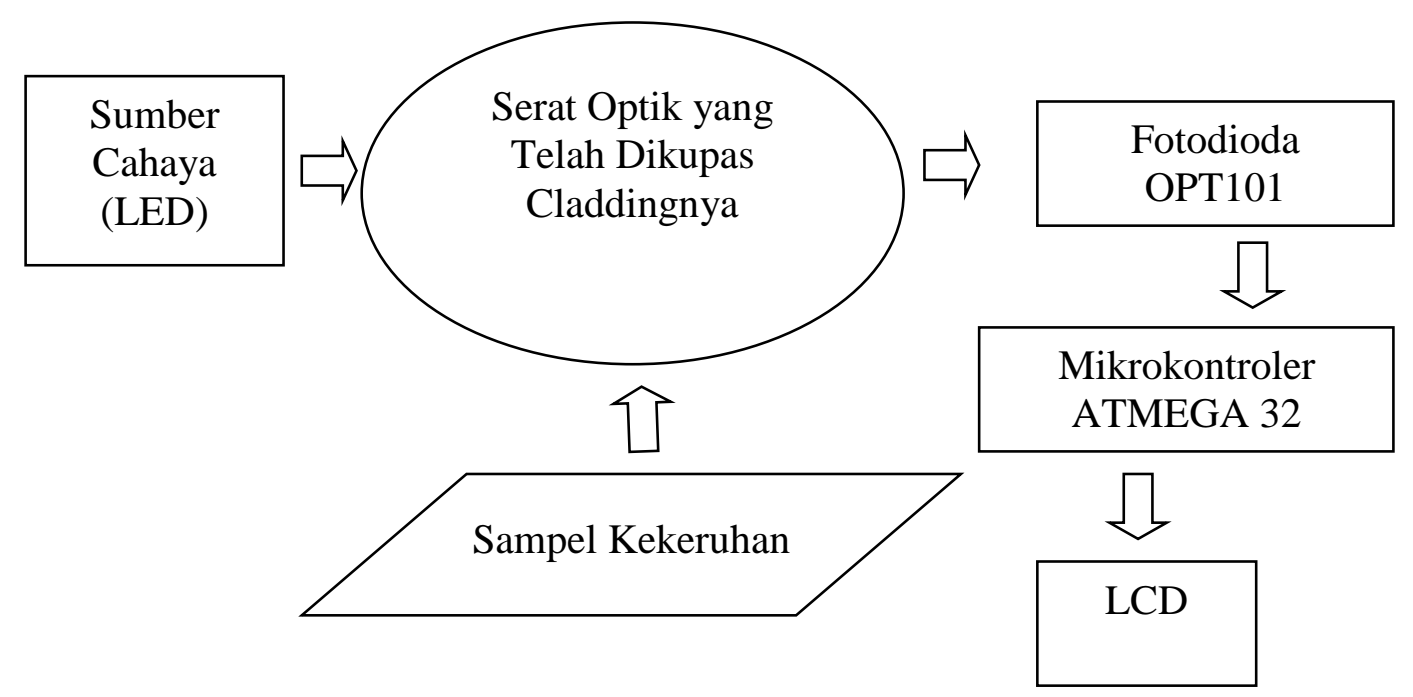

Gambar 1. Blok diagram sistem sensor serat optik untuk kekeruhan air

Gambar 1 menggambarkan blok diagram dari keseluruhan sistem sensor serat optik untuk pengukuran tingkat kekeruhan air. Serat optik yang telah dikupas claddingnya dimasukkan kedalam sampel kekeruhan air. Serat optik disinari oleh sumber cahaya, dimana sampel kekeruhan akan menjadi cladding pengganti dari cladding yang telah dikupas. Cahaya yang menjalar dalam serat optik akan dideteksi oleh detektor. Detektor mendeteksi cahaya tersebut bergantung kepada kerapatan dan kekentalan dari sampel kekeruhan. Keluaran dari detektor berupa tegangan kemudian dirubah ke bentuk bilangan biner oleh ADC internal pada mikrokontroler. Data akan diproses oleh mikrokontroler sesuai dengan program yang didesain. Hasil proses mikrokontroler ditampilkan melalui LCD.

Pengujian pengaruh pembengkokan terhadap keluaran sensor dilakukan dengan menggunakan sistem seperti huruf U. Kabel serat optik yang dibengkokkan pada bagian ujungnya diletakkan LED sebagai pemancar dan photodioda sebagai detektor. Pegujian dilakukan dengan memvariasikan jarak antara sumber dengan detektor. Pembengkokan kabel serat optik pada sistem sensor ini diperlihatkan seperti Gambar 2.

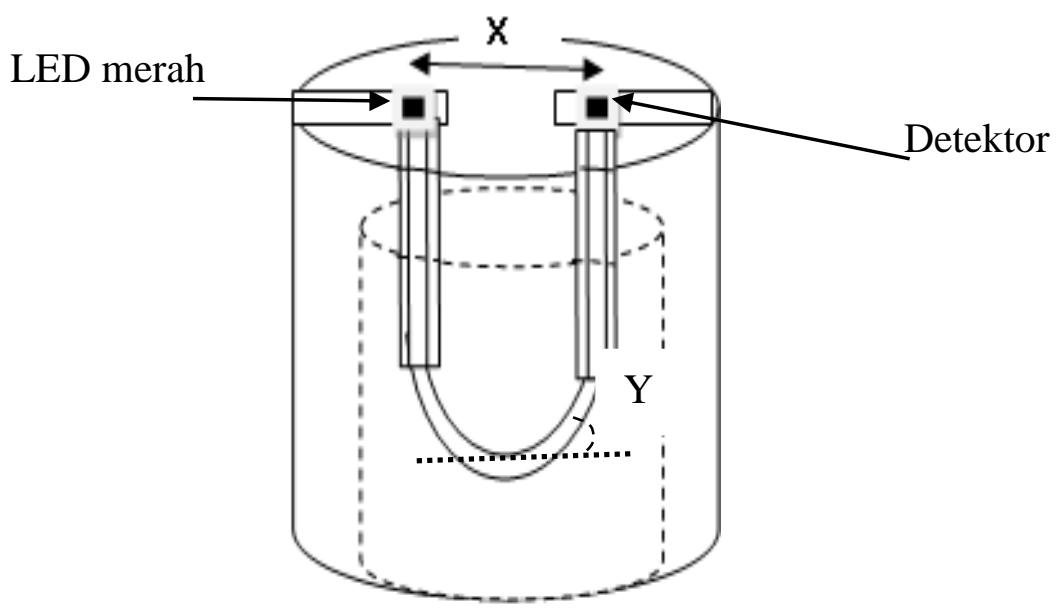

Gambar 2. Set up pembengkokan kabel serat optic dengan model U-System

Gambar 2 memperlihatkan set up peralatan untuk melihat pengaruh pembengkokan kabel serat optik terhadap tegangan keluaran sensor. Jarak divariasikan antara sumber dengan 
detektor yang diperlihatkan dengan simbol $\mathrm{x}$, sedangkan sudutnya disimbolkan dengan simbol Y.

\section{HASIL DAN DISKUSI}

Sistem pengukuran kekeruhan air ini menggunakan sistem sensor serat optik dengan metode evanescent. Serat optik melakukan penginderaan dengan cara memodifikasi cladding serat optik. Memodifikasi cladding bisa dilakukan dengan mengupas cladding asli serat optik, sehingga nantinya sampel air yang digunakan menjadi claddingnya. Serat optik disinari oleh sumber cahaya, dimana sampel kekeruhan akan menjadi cladding pengganti dari cladding yang telah dikupas. Cahaya yang menjalar dalam serat optik akan dideteksi oleh detektor. Detektor mendeteksi cahaya tersebut bergantung kepada kerapatan dan kekentalan dari sampel kekeruhan. Hasil perancangan kabel serat optik sebagai sistem sensor kekeruhan air seperti pada Gambar 3.

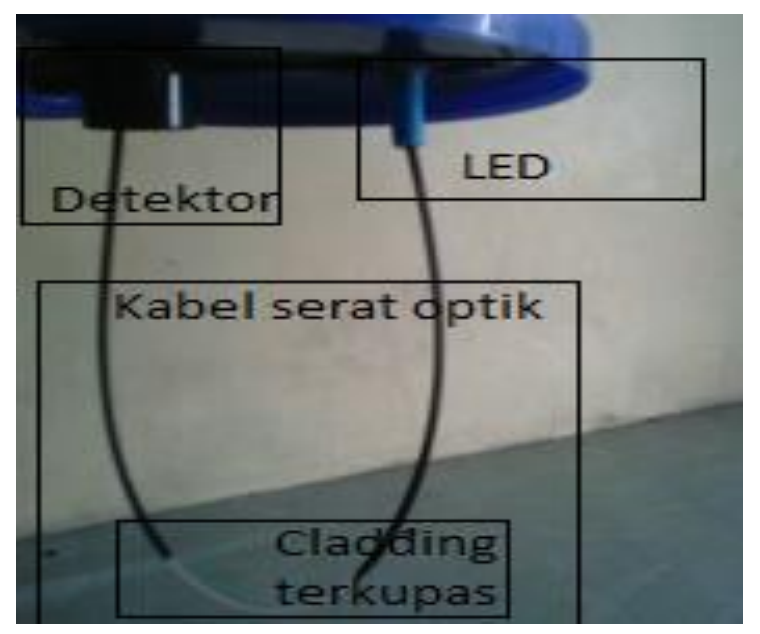

Gambar 3. Sistem sensor Serat Optik yang Dirancang

Gambar 3 memperlihatkan hasil dari perancangan kabel serat optik sebagai sensor. Sistem sensor ini dibuat dengan memodifikasi cladding kabel serat optik. Sistem sensor serat optik ini terdiri dari fotodetektor, LED sebagai sumber cahaya, serat optik, dan serat optik yang dikupas claddingnya.

Untuk mengetahui pengaruh pembengkokan (bending) terhadap keluaran sensor maka dilakukakan pengukuran dengan variasi jarak antara sumber dengan detektor, dimana perubahan jarak ini akan mengakibatkan perubahan pada sudut pembengkokan. Perubahan yang dilakukan terhadap jarak juga akan berpengaruh pada sudut pembengkokan dari serat optik, sehingga data yang diambil merupakan data keluaran sensor dari tiga variasi sudut pembengkokan. Tiga variasi sudut yang dilakukan dalam pengujian ini yaitu $14^{0}, 22^{0}$, dan $28^{\circ}$. Pengaruh pembengkokan pada variasi sudut diperlihatkan Gambar 4. 


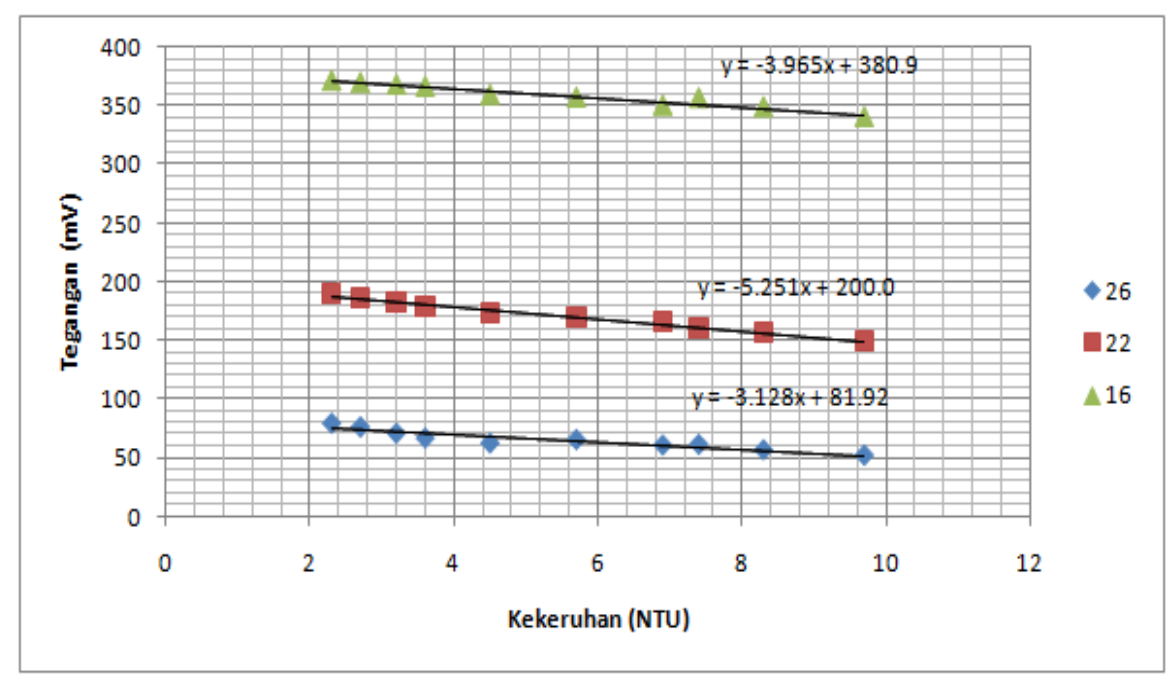

Gambar 4. Hubungan tegangan sensor dengan kekeruhan

Dari Gambar 4 terlihat bahwa ketiga variasi sudut menggambarkan tegangan keluaran sensor semakin berkurang seiring pertambahan kekeruhan air yang diukur. Penurunan tegangan keluaran sensor berhubungan secara linier dengan kekeruhan air. Melalui pendekatan garis lurus diperoleh persamaan hubungan antara tegangan keluaran dengan kekeruhan. Rugi daya pembengkokan terjadi pada saat sinar melalui serat optik yang dibengkokkan, dimana sudut datang sinar lebih kecil dari pada sudut kritis sehingga sinar tidak dipantulkan sempurna tetapi dibiaskan .

Secara keseluruhan pada masing-masing variasi sudut mengalami hal yang sama, yaitu semakin besar kekeruhan yang diberikan semakin besar rugi daya yang terjadi. Hal yang membedakan adalah kemiringan pendekatan garis linearnya. Pada sudut $22^{\circ}$ kemiringannya paling curam jika dibandingkan dengan yang lainnya. Hal ini berkaitan dengan sensitivitas dari sensor, jika lekukan yang diberikan semakin besar akan menyebabkan semakin sensitifnya sensor. Namun dari tiga data penelitian ini apabila sudut diperbesar lagi maka sensitivitasnya akan berkurang. Hal ini disebabkan oleh faktor luar seperti tekanan dan regangan pada serat optik. Semakin ditekuk maka tekanan dan regangan pada serat optik akan semakin besar dan akan menyebabkan perubahan struktur dari serat optik itu sendiri.

\section{KESIMPULAN DAN SARAN}

Sistem sensor serat optik memanfaatkan perubahan tegangan keluaran fotodioda akibat perubahan kekeruhan air. Sistem sensor serat optik digunakan untuk mengukur tingkat kekeruhan air dengan melakukan pembengkokan seperti huruf $U$, dimana pada bagian ujungnya masing-masing terdapat LED dan detektor. Pengukuran dilakukan dengan tiga variasi sudut pembengkokan. Semua variasi sudut memperlihatkan semakin besar konsentrasi kekeruhan larutan yang diberikan maka semakin besar rugi daya yang dialami. Hal yang membedakan adalah kemiringan pendekatan garis linearnya yang disebut sensitivitas. Namun pada hasil penelitian yang diperoleh keadaan dimana apabila sudut diperbesar lagi maka sensitivitasnya akan berkurang.

Saran sebagai tindak lanjut dari penelitian ini yaitu penelitian perlu diteliti lebih dalam lagi dari beberapa variasi sudut pembengkokan sehingga didapatkan sensitivitas maksimum pada jarak antar kaki yang berbeda. Perlu ditinjau ulang titik kritis masingmasing pengukuran. 


\section{DAFTAR PUSTAKA}

1. Khanafiah, S., dkk., 1999, Fisika Lingkungan. Fisika FMIPA UNNES, Semarang.

2. Wibowo, R., Rubiyanto, A., 2012, Desain Sensor Konsentrasi Larutan $\mathrm{NaCl}$ Menggunakan Serat Optik moda Jamak Dengan Model W system, Jurnal Sains dan Seni ITS, Vol. 1, No.1, B70-B72.

3. Erick, UDD., 1990, Fiber Optic Sensor An Introduction for engineers and scientist, United States of America.

4. Allard., Federick, C., 1990, Fiber Optics Handbook, McGraw-Hill, United States.

5. Maddu, A., dkk., 2006, Pengembangan Probe Sensor Kelembaban Serat Optik Dengan Cladding Gelatin, Makara Teknologi, Vol. 10, NO. 1, 45-50. 